\section{Cold results from Utah}

\section{Washington}

AN announcement last week by the University of Utah in Salt Lake City that physicists there had achieved nuclear fusion in a test tube at room temperature has been followed by a flurry of speculation about not only the strange science involved but also the peculiar publicity given to it.

The technique involves nothing more complicated than electrochemistry. Current is passed through a palladium electrode immersed in a solution of various salts in deuterated water. Over a period of many hours, deuterium atoms are absorbed by the palladium lattice in such numbers that some of them fuse, forming tritium or helium-3, simply because of their proximity. A return of four watts of heat from one watt of electricity was reportedly obtained when current was passed for a total of 100 hours.

According to James Brophy, vice president for research at the University of Utah, the decision to announce the work in preliminary form at a press conference last Thursday, before a paper had been accepted by a scientific journal, was a response to press enquiries. But the university press office had previously contacted several science reporters and encouraged them to attend.

A statement by the University of Utah that results "will appear in the scientific literature in May", coupled with a report in last Thursday's Wall Street Journal that papers had been submitted to $\mathrm{Na}$ ture, provoked numerous telephone calls to Nature's Washington office enquiring whether we had accepted or were about to publish one or more papers. (The answer is no.) Meanwhile, a group at Brigham Young University in Provo, Utah, led by Steven E. Jones, has refused to say whether they have obtained similar results.

Enthusiasm over the claim has been tempered with a good deal scepticism, not only due to the lack so far of a detailed account but also because the history of fusion research has been regularly punctuated by 'breakthroughs'. The new claim bears some similarity to muon-catalysed fusion, in which the substitution of a muon for an electron in heavy hydrogen shrinks the size of the molecule enough for spontaneous fusion of the two deuterons to occur. Reasonable rates have been achieved in smallscale experiments, but as an energyproducing method muon fusion is no nearer success than any other technique. The University of Utah has applied for a patent on its technique, but Jones says only "don't sell your oil stocks yet". $\square$

\title{
Academy starts over again
}

\section{Moscow}

AT the general meeting last week of the Academy of Sciences of the USSR, only 8 of 20 delegates were elected to the AllUnion Congress, from which delegates will ultimately be elected to the Supreme Soviet of the USSR. The Academy's election process will now have to begin again.

The normal election procedure was complicated by the fact that after an extended plenum of the leading bodies of the Academy on 18 January, just 23 candidates for the 20 delegates out of 130 candidates proposed by research teams at academic institutions were chosen (see Nature 337, 293; 1989). The failure to nominate those scientists receiving the greatest popular support-including Academicians Andrei Sakharov and Roald Sagdeev-evoked particular discontent. A lobby was set up for the democratic election of People's Deputies from the Academy of Sciences of the USSR, which held a protest meeting in front of the Academy Praesidium's building in Moscow, and organized what amounted to a boycott of the election of the nominated candidates.

According to the law, additional elections have to be held to fill the remaining 12 delegates within the next two months. The new election process began during last week's general meeting, when procedures and potential candidates were discussed. Describing the outcome of the elections in his speech at the conference, Sakharov emphasized that emotions were running so high not because "Sakharov was not nominated, but because the role of the research institutions was ignored".
Academician G.I. Marchuk, president of the Academy, explained the current election phenomenon by saying that "all of Soviet society, including the Academy, is going through a historical moment--the transition to people's power has started in the USSR in earnest. The main point is that the elected deputies will represent not just the interests of the Academy but also and above all the interests of the social development of the nation as a whole."

Voting procedures now call for the 15 unsuccessful candidates to be asked to agree to run again. In addition, many scientists from the previous list suggested by various institutes, as well as new names, were mentioned. Judging by the response of the audience, the following scientists should be on the list of new candidates: Academician Stanislav Shatalin, an economist; Academician Vitaly Ginsburg, a physicist; and the economist Nikolai Shimeley. New elections will probably be held next month.

The conference decided that new candidates will be nominated by the Praesidium of the Academy of Sciences of the USSR. This responsibility has now been vested in it after the extended plenum of the leading bodies of the Academy failed to rise to the occasion. The members of the former election commission of the Academy of Sciences on the election of People's Deputies have resigned, and a new commission will be formed. The date for a new election conference has not yet been fixed. Importantly, the voting will be by secret ballot at meetings of research associates of academic institutes.

Yuri Kanin Novosti

\section{WEATHER FORECASTING}

\section{Precipitation precipitates complaints}

\section{Sydney}

AN insufficient number of weather stations are being blamed for Australian weather forecasters' failure to provide early warning of torrential rains that flooded parts of central Australia, causing significant stock losses. Rains have been particularly heavy in Australia this year. At Broken Hill, in western New South Wales, 180 millimetres of rain fell in a slightly more than $\mathbf{2 4}$ hours, the heaviest fall that had been recorded since 1973 . Storm warnings by the Department of Meteorology came on the morning of the fall, too late for some farmers.

A reduction in staff salaries and productivity costs means much of Australia weather remains undetected. "We have a country the size of the United States with one tenth its population. The quality of our meteorological services is related to the observational networks we can afford", said Bill Downey, assistant executive director for the Australian Bureau of Meteorology.

Peter Noar, assistant director of weather services, acknowledges that a full network of a couple of hundred observation stations is needed. Some help may come from plans to expand land-based automatic weather stations and improve the network for aviation forecasting.

But the problems at Broken Hill are threatening to get worse before they get better. The Civil Aviation Authority airport observation station may close, forcing the Bureau of Meteorology to try to come up with sufficient funds to open its own station in Broken Hill.

Tania Ewing 